\title{
Escherichia coli Contamination of Lettuce Grown in Soils Amended with Animal Slurry
}

\author{
A. N. JENSEN, ${ }^{1 *}$ C. STORM, ${ }^{1}$ A. FORSLUND, ${ }^{2}$ D. L. BAGGESEN,${ }^{1}$ AND A. DALSGAARD ${ }^{2}$
}

${ }^{1}$ Division of Food Microbiology, National Food Institute, Technical University of Denmark, Bülowsvej 27, 1790 Copenhagen V, Denmark; and ${ }^{2}$ Department of Veterinary Disease Biology, Faculty of Health and Medical Sciences, University of Copenhagen, Denmark, Stigböjlen 4, 1870 Frederiksberg C, Denmark

MS 13-011: Received 10 January 2013/Accepted 27 February 2013

\begin{abstract}
A pilot study was conducted to assess the transfer of Escherichia coli from animal slurry fertilizer to lettuce, with E. coli serving as an indicator of fecal contamination and as an indicator for potential bacterial enteric pathogens. Animal slurry was applied as fertilizer to three Danish agricultural fields prior to the planting of lettuce seedlings. At harvest, leaves ( $25 \mathrm{~g})$ of 10 lettuce heads were pooled into one sample unit $(n=147)$. Soil samples $(100 \mathrm{~g})$ were collected from one field before slurry application and four times during the growth period $(n=75)$. E. coli was enumerated in slurry, soil, and lettuce on 3M Petrifilm Select $E$. coli Count Plates containing $16 \mathrm{mg} /$ liter streptomycin, $16 \mathrm{mg} /$ liter ampicillin, or no antimicrobial agent. Selected E. coli isolates $(n=83)$ originating from the slurry, soil, and lettuce were genotyped by pulsed-field gel electrophoresis (PFGE) to determine the similarity of isolates. The slurry applied to the fields contained 3.0 to $4.5 \log \mathrm{CFU} / \mathrm{g}$ E. coli. E. coli was found in 36 to $54 \%$ of the lettuce samples, streptomycin-resistant $E$. coli was found in 10.0 to $18.0 \%$ of the lettuce samples, and ampicillinresistant $E$. coli in 0 to $2.0 \%$ of the lettuce samples (the detection limit was $1 \log C F U / g$ ). The concentration of $E$. coli exceeded 2 $\log$ CFU/g in $19.0 \%$ of the lettuce samples. No E. coli was detected in the soil before the slurry was applied, but after, $E$. coli was present until the last sampling day (harvest), when 10 of 15 soil samples contained $E$. coli. A relatively higher frequency of $E$. coli in lettuce compared with the soil samples at harvest suggests environmental sources of fecal contamination, e.g., wildlife. The higher frequency was supported by the finding of 21 different PFGE types among the $E$. coli isolates, with only a few common PFGE types between slurry, soil, and lettuce. The frequent finding of fecal-contaminated lettuce indicates that human pathogens such as Salmonella and Campylobacter can be present and represent food safety hazards.
\end{abstract}

In recent years, an increasing number of disease outbreaks in humans have been associated with consumption of contaminated vegetables $(4,15,24,35)$, and most of Ithe outbreaks during 1996 to 2008 were associated with . ㄱeafy green vegetables, where Escherichia coli O157:H7 and Salmonella spp. accounted for $72 \%$ of the pathogens Involved (21). Sprouts were the likely source of a large European outbreak of E. coli O104:H4 originating in Germany (7), and a multistate (United States) disease nutbreak of E. coli $\mathrm{O} 157: \mathrm{H7}$ in October 2011 was linked to romaine lettuce (9). The point of contamination of such vegetables is, however, only rarely identified (8). Critical points of preharvest contamination with pathogens in the vegetable production chain are the result of untreated animal manure as well as irrigation with contaminated water or runoff water from nearby areas with animal fecal deposits. Thus, it has been speculated as to what extent human disease outbreaks are associated with the application of animal manure as fertilizer, which is a common practice

\footnotetext{
* Author for correspondence. Present address: Mørkhøj Bygade 19, 2860 Søborg, Denmark. Tel.: +45-35886328; Fax: +45-35887001; E-mail: anyj@food.dtu.dk.
}

in organic vegetable production, because application of mineral nitrogen fertilizers are prohibited (18).

Animal manure is a potential source of zoonotic pathogens such as Salmonella, Campylobacter, verotoxinproducing $E$. coli, and protozoan parasites, because many animals shed these pathogens asymptomatically in their feces $(2,19,27)$. Pathogens persist in manure for a variable length of time, depending on the storage conditions, e.g., in stacked heaps or slurry tanks, which affect heat development, a main determinant of pathogen survival $(5,20,22$, 26,39 ). When fresh or inadequately stored manure is used to fertilize vegetable crops, the pathogens present contaminate the soil, where their survival can vary from a few days to several months $(29,30)$. Consequently, lettuce seedlings planted in animal slurry-amended soil are exposed to persistent pathogens either through roots embedded in the contaminated soil or via splash onto the leaf surface during irrigation or rain events.

Under open-land conditions, vegetables can also be exposed to pathogens originating from the surrounding wildlife or other environmental sources $(13,47)$. The possible routes of fecal transmission of pathogens under field conditions are numerous, but application of DNA-based fingerprint methods such as pulsed-field gel electrophoresis 
(PFGE) can help track the source of fecal bacteria (45). Surveys on the type and concentrations of pathogens on vegetables and their survival under natural field conditions are still scarce, although increasing (38). The reported level of human pathogens in produce seems to vary considerably, e.g., between regions $(3,32,41,50)$. It is uncertain as to what extent pathogens present in the soil can become internalized into the plant through the root system or be transferred to leaf surfaces through rain splash, with possible internalization via leaf orifices, but both transmission routes constitute potential food safety risks for consumers $(6,16,37,46)$. Moreover, the human health implications from pathogens present in readyto-eat produce are enhanced if the pathogens display resistance to antimicrobials, as it can lead to treatment failure in humans (51). However, not only findings of resistant human pathogens are of concern, but also antimicrobial resistance genes can be transferred between bacteria via horizontal gene transfer, as proposed for extended-spectrum $\beta$-lactamase genes in gram-negative bacteria on spinach (23, 25,42 ).

This pilot study assessed the level of E. coli contamination and the antimicrobial resistance in $E$. coli found on lettuce grown on open fields fertilized with organic or conventional animal slurry. The PFGE genotypes of E. coli isolated from slurry, soil, and lettuce were compared in order to investigate the possible source of $E$. coli isolated from lettuce.

\section{MATERIALS AND METHODS}

Field sites. Three main Danish producers of organic lettuce on open fields who apply animal slurry as fertilizer were selected for sampling of lettuce under field conditions. The three field sites were located on Central Funen (fields 1 and 3) and in Southern Jutland (field 2), and the soil in the fields was characterized as loamy. According to weather data from the Danish Meteorological Institute, the precipitation for Funen was 24, 26, 47, and $135 \mathrm{~mm}$ per month from May to August, respectively. On two occasions, the daily precipitation was $>10 \mathrm{~mm}$, once in the beginning of the growth period for field $1(12 \mathrm{~mm})$ and once at the end of the growth period for field $3(20 \mathrm{~mm})$. From May to August, the monthly average temperature was $13.0,15.3,17.8$, and $17.0^{\circ} \mathrm{C}$, with a total of $362,293,281$, and $160 \mathrm{~h}$ of sun per month, respectively. In Southern Jutland (field 2), the precipitation was 6, 43 , and $57 \mathrm{~mm}$ per month from May to July, respectively, and the daily precipitation did not exceed $10 \mathrm{~mm}$ per day within this period. In this area, the monthly average temperature was 13.0, 15.2 , and $17.4^{\circ} \mathrm{C}$, with a total of 333,272 , and $248 \mathrm{~h}$ of sun per month, respectively. The animal slurry was applied 7 days (field 1), 72 days (field 2), and 0 days (field 3) prior to planting of lettuce seedlings. Details on the application of the animal slurry are provided below. The slurry was applied on plowed fields at a rate of $25 \mathrm{~m}^{3} / \mathrm{ha}$ and incorporated into the soil by harrowing within $2 \mathrm{~h}$ after application to minimize nitrogen evaporation.

Soil samples were collected from field 3 only and analyzed for the presence and concentration of E. coli. Surface top soil (0 to $5 \mathrm{~cm}$ ) was collected for every $10 \mathrm{~m}$ along a longitudinal transect of $150 \mathrm{~m}$ (referred to as soil locations 1 to 15) on five occasions, before slurry application (control sample) and after slurry application on days $8,12,19$, and 33 (at harvest), yielding a total of 75 soil samples. A total of approximately $100 \mathrm{~g}$ of surface soil was collected for each sample, with a sterile spoon from five sites within a diameter range of $25 \mathrm{~cm}$ from the lettuce seedling and collected in a clean plastic container, which was kept at ambient temperature during transport to the laboratory. The samples were stored at 4 to $5^{\circ} \mathrm{C}$ until the following day, when the soil was mixed by hands wearing plastic gloves, before $5 \mathrm{~g}$ was weighed for enumeration of $E$. coli.

Animal slurry fertilizer. The animal slurry used as fertilizer originated from a conventional pig farm (field 1), four farms raising organic cattle (field 2), and an organic cattle farm (field 3). The slurry was transported from the livestock farms to the lettuce grower, where it was stored before application. The only exception was for the slurry used in field 3 , where the slurry remained at the organic cattle farm until distributed onto the field. The overall storage time for the slurry was $<1$ month for field $1,>6$ months for field 2 , and 3 to 6 months for field 3. Prior to application on the fields, slurry samples were collected directly from the slurry tanks with a clean 12-liter bucket and then transferred to sterile $500-\mathrm{ml}$ plastic bottles. The bottles were placed in insulated boxes with cooling elements and transported to the laboratory for analysis within $24 \mathrm{~h}$. Bottles with slurry were gently shaken to obtain a homogenized solution, before 5 -g subsamples were collected for enumeration of $E$. coli.

Lettuce. Seedlings of lettuce (Lactuca sativa) were planted at the end of May (fields 1 and 2) and early July (field 3 ) in rows with a distance of 35 to $40 \mathrm{~cm}$ between each plant and with an overall density of 40,000 to 50,000 lettuce seedlings per ha. The lettuce was sprinkler irrigated with groundwater during the growth period, which lasted 50 days for field 1, 57 days for field 2, and 33 days for field 3. No bacteriological testing was done of the groundwater used for irrigation in this study, as the microbiological water quality and absence of $E$. coli contamination is regularly ensured by the relevant national authorities. At harvest, lettuce heads were randomly selected and cut with disposable scalpels $1 \mathrm{~cm}$ above the ground, avoiding the coarse outer leaves. Ten lettuce heads were pooled into one sample (sample unit) and placed in a sterile plastic bag that was stored at 4 to $5^{\circ} \mathrm{C}$ until analysis was initiated the following day. A total of 50 (iceberg, L. sativa var. capitata), 47 (23 iceberg and 24 romaine lettuce, L. sativa var. longifolia) and 50 (loose-leaf lettuce, L. sativa var. crispa) sample units were collected at fields 1,2 , and 3, respectively. On field 3, 15 of the lettuce sample units were each collected from three rows in proximity to each of the 15 locations where soil samples were collected as described above.

From each of the sample units (each consisting of 10 lettuce heads), a total of $25 \mathrm{~g}$ of inner and outer leaves was cut in a standardized manner by a sterile disposable scalpel to form a $250-\mathrm{g}$ sample. This sample was blended at full speed in a kitchen blender approximately 1 min until a homogenous paste was obtained, from which a 5-g subsample was obtained for immediate enumeration of E. coli.

Enumeration, isolation, and antimicrobial susceptibility of $\boldsymbol{E}$. coli. Concentrations of $E$. coli in the slurry, lettuce, and soil samples were enumerated by plate counting by using Petrifilm Select E. coli Count Plates (SEC plates; 3M, St. Paul, MN). Tenfold dilution series were prepared by initial homogenization of sample material in a Stomacher 80 (Seward, Ltd., Worthing, UK) by adding $5 \mathrm{~g}$ of the homogenized samples to $45 \mathrm{ml}$ of $0.9 \% \mathrm{NaCl}$ solution containing $0.1 \%$ peptone (Bacto Peptone, BD, Franklin Lakes, NJ). Following the manufacturer's instructions, $1 \mathrm{ml}$ of appropriate dilutions was added onto SEC plates. Additionally, $1 \mathrm{ml}$ of each dilution was mixed with $50 \mu \mathrm{l}$ of streptomycin or 
ampicillin stock solution before transfer onto SEC plates, yielding a final antimicrobial concentration of $16 \mathrm{mg} /$ liter on the plates in order to determine the number of resistant $E$. coli according to $\mathrm{Wu}$ et al. (53). Ampicillin and streptomycin were selected, as a previous study indicated that these antimicrobials could serve as a marker for differences in the antimicrobial resistance levels in animal manure from organic and conventional production (52). The SEC plates were incubated $24 \mathrm{~h}$ at $44^{\circ} \mathrm{C}$ before colonies on plates containing 15 to $150 \mathrm{CFU}$ were enumerated.

At field 3, E. coli colonies from slurry, soil, and lettuce samples were selected randomly from the SEC plates and characterized by PFGE to compare genotypes. Thirteen E. coli were isolated from the cattle slurry applied on field 3 . Up to eight $E$. coli isolates were obtained from each soil sample collected from locations $8,9,11$, and 14 on day 8 (29 isolates in total) and from the same locations on day 33 (17 isolates in total) after the slurry was applied. E. coli from lettuce $(n=24)$ grown at these four locations was isolated from samples collected during harvest on day 33. The isolates were verified as E. coli based on their appearance on Brilliance E. coli-Coliform Selective Agar (Oxoid, Ltd., Basingstoke, UK) as well as gas production and a positive indole reaction.

PFGE typing. A total of 83 selected isolates of E. coli originating from the cattle slurry $(n=13)$, soil $(n=46)$, and lettuce $(n=24)$ from field 3 were analyzed by PFGE genotyping to discriminate between isolates and to determine the level of similarity of PFGE types. This was to indicate to what extent the $E$. coli found in the soil and on the lettuce originated from the animal slurry applied.

PFGE was performed as described by the Centers for Disease Control and Prevention's PulseNet (43). DNA was prepared directly in a solid agarose plug (SeaKem Gold Agarose, Lonza, Basel, Switzerland) for restriction endonuclease digestion with the enzyme XbaI (New England Biolabs, Ipswich, MA). The separation of fragments was done with the CHEF-DR III PFGE system (Bio-Rad, Hercules, CA), with the following conditions: $6 \mathrm{~V} / \mathrm{cm}$ at $14^{\circ} \mathrm{C}$ for $19 \mathrm{~h}$ at a field angle of $120^{\circ}$. The electrophoresis was carried out at switch times of 2.2 to $54.4 \mathrm{~s}$. Multimeric phage lambda (48.5 kb) DNA (New England Biolabs) was used as the molecular weight standard. Salmonella enterica serotype Braenderup was used as an internal control, as well as a DNA molecular weight marker. After the electrophoresis, the gels were stained for $15 \mathrm{~min}$ in ethidium bromide $(2 \mathrm{mg} / \mathrm{ml}$ in water; Sigma-Aldrich Denmark A/S, Brøndby, Denmark), destained in distilled water for $15 \mathrm{~min}$, and visualized under UV light (Gel Doc, Bio-Rad). Gel images of the PFGE profiles were imported into BioNumerics, version 4.5 (Applied Maths, Kortrijk, Belgium), and aligned with the $S$. enterica serotype Braenderup standard marker. Bands were found by auto search at a position tolerance of 1.0, and only bands between 33 and 1,135 bp were included in the analysis. A difference in one or more band locations or the number of bands was considered to represent different PFGE types.

\section{RESULTS AND DISCUSSION}

\section{$E$. coli and antimicrobial resistance contamination} of lettuce. E. coli was found in $45 \%$ (66 of 147 pools at a detection level of $>1 \log \mathrm{CFU} / \mathrm{g}$ ) of all lettuce pools. The number of $E$. coli exceeded the satisfactory microbiological hygiene criteria level of $2 \mathrm{log} \mathrm{CFU} / \mathrm{g}$ established for precut fruits and vegetables (ready to eat) (17) in $19 \%$ of the lettuce pools, whereas $99 \%$ contained $<3 \log \mathrm{CFU} / \mathrm{g}$. The level of E. coli in the lettuce pools for each of the three
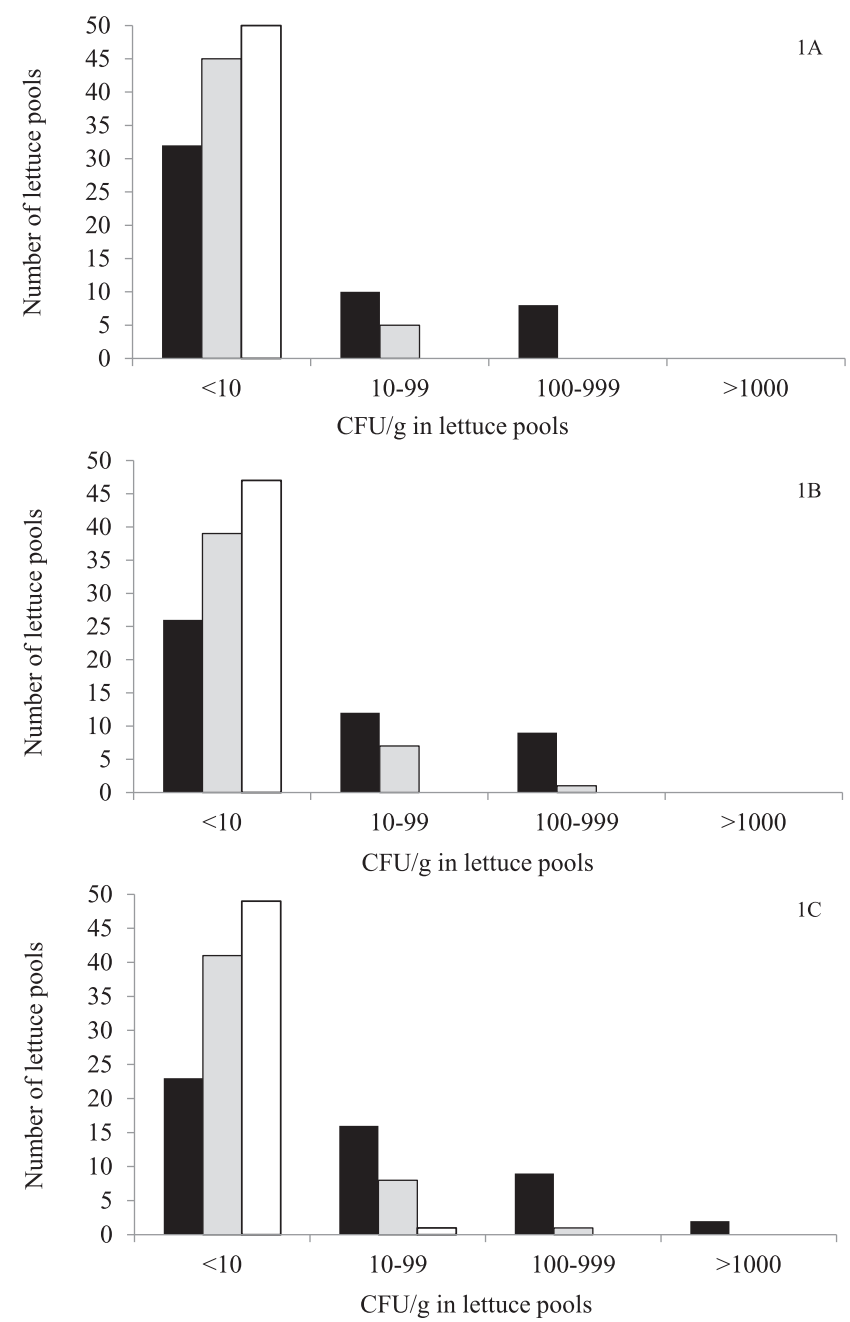

FIGURE 1. Escherichia coli contamination levels in lettuce pools and their resistance to streptomycin and ampicillin: (A) field 1 $(\mathrm{n}=50),(B)$ field $2(\mathrm{n}=47)$, and $(C)$ field $3(\mathrm{n}=50)$. Black, sensitive E. coli; gray, streptomycin-resistant E. coli; white, ampicillin-resistant E. coli.

fields is shown in Figure 1, and there appears to be relatively little difference between the three fields, irrespective of the marked differences in farming practices. No equivalent microbiological hygiene criteria have yet been established for noncut vegetables, and cutting can change the growth conditions for pathogens being present due to a change in the availability of nutrients. Nevertheless, lettuce is usually consumed raw, without any heat treatment.

The level of $E$. coli contamination is relevant, as $E$. coli serves as an indicator of fecal contamination and hence an increased risk for the occurrence of zoonotic pathogens such as Salmonella, Campylobacter, and verotoxin-producing $E$. coli that are excreted in feces by animals (49). A Shigella sonnei outbreak associated with baby corn was, e.g., correlated with the findings of high numbers of $E$. coli (34), and the numbers of $E$. coli in fresh herbs tested positive for Salmonella spp. were greater than $2 \mathrm{log} \mathrm{CFU} / \mathrm{g}$ (2). The occurrence of $E$. coli in the present study seems high in comparison with a study on ready-to-eat organic vegetables in the United Kingdom, where $1.5 \%(n=3,200)$ 
TABLE 1. Escherichia coli in soil and lettuce collected from field 3 at different periods after animal slurry application

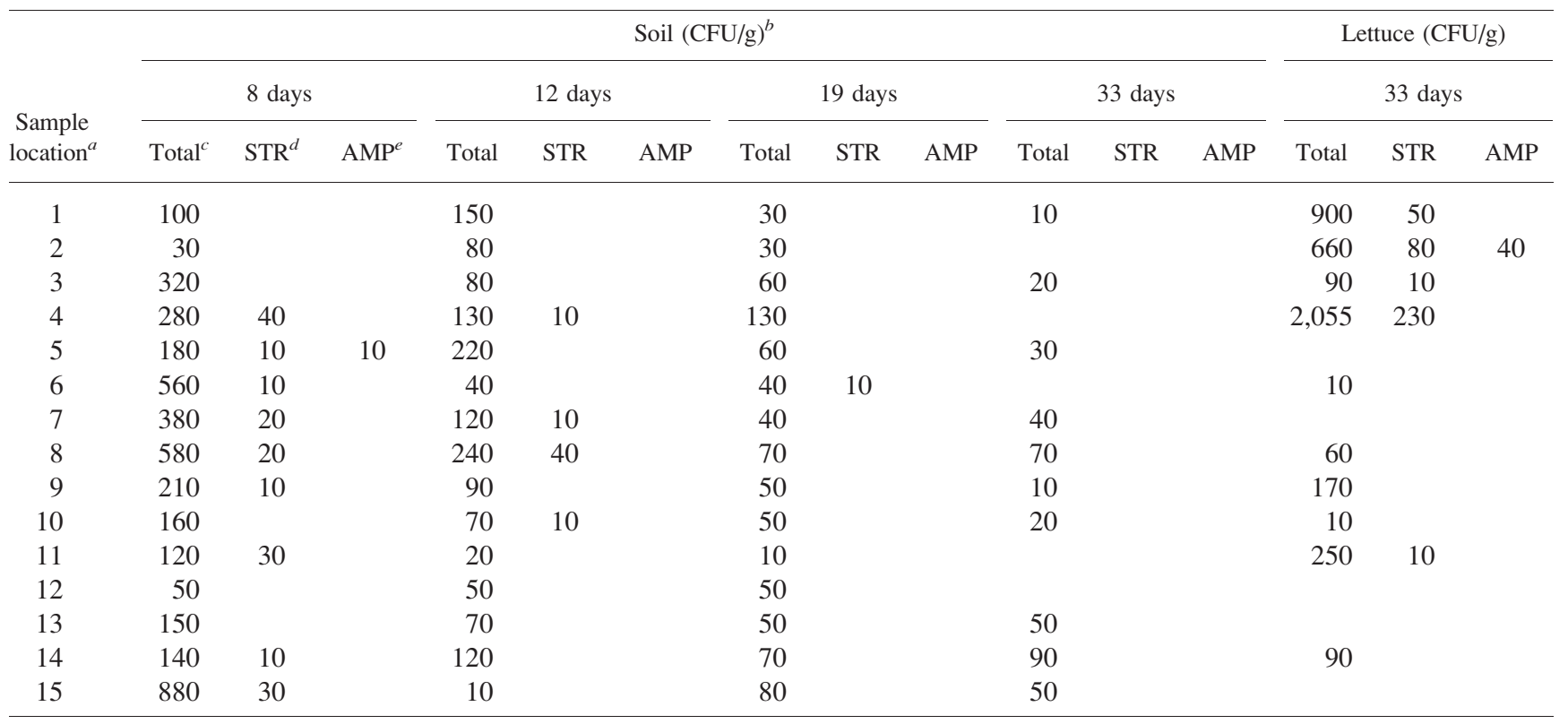

${ }^{a}$ Soil was collected for every $10 \mathrm{~m}$ along a $150-\mathrm{m}$ longitudinal transect, and 10 lettuce heads making up one pooled sample were collected in proximity to each of the 15 sampling locations.

${ }^{b}$ Days after slurry application; day 33 was the normal harvest time of lettuce. No E. coli was detected in soil before slurry application.

${ }^{c}$ Total, E. coli enumerated on SEC plates without antimicrobials.

${ }^{d}$ STR, E. coli enumerated on SEC plates with $16 \mathrm{mg} /$ liter added streptomycin.

${ }^{e}$ AMP, E. coli enumerated on SEC plates with $16 \mathrm{mg} /$ liter added ampicillin.

were positive for E. coli, and just $0.3 \%$ exceeded the satisfactory level of $2 \log \mathrm{CFU} / \mathrm{g}$ (44).

E. coli was found in 36,45 , and $54 \%$ of the lettuce pools ( $n=147$ in total) collected from fields 1,2 , and 3, respectively. The frequent finding of $E$. coli contamination in lettuce pools $(45 \%)$ is in contrast to Johannessen et al. (31), who reported no transmission of E. coli $\mathrm{O} 157: \mathrm{H} 7$ to crisphead lettuce grown during a 50-day study period in soil fertilized with bovine manure inoculated with $4 \log \mathrm{CFU} / \mathrm{g}$ E. coli $\mathrm{O} 157: \mathrm{H} 7$, although E. coli $\mathrm{O} 157: \mathrm{H} 7$ persisted in the soil for at least 8 weeks. In another experiment, where the $E$. coli $\mathrm{O} 157: \mathrm{H} 7$ inoculation level was $3 \mathrm{log}$ higher (7 log $\mathrm{CFU} / \mathrm{g}$ of compost), lettuce tested positive 77 days after the seedlings were planted (30). In comparison, the slurry applied in our study contained 4.5 (field 1), 3.0 (field 2), and 3.9 (field 3) $\log \mathrm{CFU} / \mathrm{g}$ E. coli.

Dissimilarities in leaf surface area as well as structure can, in relation to the climatic conditions, influence the likelihood of $E$. coli contamination and persistence (6). Three different cultivars of $L$. sativa (iceberg, romaine, and loose-leaf lettuce) were harvested at the three fields in the current study due to practical reasons, and it is uncertain as to what extent different characteristics of the leaf surfaces did influence contamination with E. coli. Heavy rain events can promote splashing with contaminated matter onto edible parts of the crops, whereas solar radiation increases pathogen die-off (10). However, it is uncertain if the observed climatic variations from the end of May to the beginning of August, e.g., involving a rain event of $20 \mathrm{~mm}$ on field 3 the day before harvest, had a significant impact on the E. coli contamination levels.
In the slurries applied to fields 1,2 , and $3,42.4,4.2$, and $0.3 \%$ of the E. coli isolates were resistant to streptomycin, respectively, while $19.2,3.2$, and $0.1 \%$ of $E$. coli isolates were resistant to ampicillin. Thus, the highest prevalence of antimicrobial resistance was found in the conventional pig slurry, whereas less than $5 \%$ of E. coli was resistant to streptomycin and ampicillin in the organic cattle slurry. This difference is a likely consequence of the restrictions on antimicrobial usage in organic production systems, as was previously observed for organic and conventional pigs (52). However, part of this difference might also relate to the animal species, as the bacterial antimicrobial resistance level generally appears higher in pigs than in cattle (14). At harvest, streptomycin-resistant $E$. coli was found in 10.0, 17.0, and $18.0 \%$ of the lettuce pools harvested at fields 1, 2, and 3, respectively. Ampicillinresistant $E$. coli $(2 \%)$ was found only in lettuce from field 3. However, resistant E. coli was typically present in lower numbers than susceptible $E$. coli, as streptomycin-resistant E. coli exceeded a concentration of $2 \mathrm{log} \mathrm{CFU} / \mathrm{g}$ in only two (1.4\%) samples (Fig. 1).

The highest percentage of lettuce pools with resistant $E$. coli (18\% for streptomycin and $2 \%$ for ampicillin) was unexpectedly found on the field fertilized with organic cattle slurry containing few resistant $E$. coli and not the conventional pig slurry that initially had the highest concentration of resistant E. coli. In our study, lettuce was found to be contaminated with streptomycin-resistant $E$. coli, although in lower numbers than susceptible E. coli (Fig. 1). Osterblad et al. (40) also reported generally low levels of antimicrobial-resistant bacteria in vegetables, and 
TABLE 2. PFGE types of selected Escherichia coli $(\mathrm{n}=83)$ isolated from organic cattle slurry, soil after slurry application, and from lettuce grown in the slurry-amended soil in field 3

\begin{tabular}{|c|c|c|c|c|c|c|c|c|c|c|c|c|c|c|c|c|c|c|c|c|c|c|c|c|c|}
\hline $\begin{array}{l}\text { Sample } \\
\text { type }\end{array}$ & $\begin{array}{c}\text { Sample } \\
\text { location }^{a}\end{array}$ & $\begin{array}{l}\text { Time } \\
(\text { days })^{b}\end{array}$ & $n$ & E. coli/g & \multicolumn{21}{|c|}{ PFGE type $^{c}$ : } \\
\hline Soil & 8 & 8 & 7 & 580 & & & & & & 2 & 1 & & 1 & 1 & 2 & & & & & & & & & & \\
\hline Soil & 8 & 33 & 8 & 70 & & & & & & 1 & 2 & 1 & 1 & 1 & & 1 & & 1 & & & & & & & \\
\hline Lettuce & 8 & 33 & 3 & 60 & & & & & & & & & & & & & & & & & & & & & 3 \\
\hline Lettuce & 9 & 33 & 5 & 70 & & & & & & & & & & 1 & & & & & & & & & 3 & 1 & \\
\hline Soil & 11 & 8 & 8 & 120 & & & & & & 2 & 2 & & 4 & & & & & & & & & & & & \\
\hline Soil & 11 & 33 & 0 & 0 & & & & & & & & & & & & & & & & & & & & & \\
\hline Lettuce & 11 & 33 & 10 & 250 & & & & & & & & & 4 & & & & & & & 6 & & & & & \\
\hline Soil & 14 & 8 & 7 & 140 & & & & & & 1 & 4 & & & 2 & & & & & & & & & & & \\
\hline
\end{tabular}

${ }^{a}$ Soil and lettuce were collected from 4 of 15 locations along a 150-m longitudinal transect.

${ }^{b}$ Number of days after application of slurry on the field; lettuce was harvested on day 33 .

${ }^{c}$ Number of $E$. coli isolates with a particular PFGE type.

this did not seem to explain the high prevalence of resistant Enterobacteriaceae in the human intestine.

Persistence of $\boldsymbol{E}$. coli in soil. No $E$. coli was detected in soil before the application of slurry in field 3, whereas $E$. coli was found in all 15 soil samples collected on days 8,12 , and 19 (Table 1). Slurry applied to field 3 contained $3.9 \mathrm{log}$ $\mathrm{CFU} / \mathrm{g}$ E. coli. At the first sampling after slurry application on day 8 , a total of 13 of 15 soil samples had E. coli concentrations between 2 and $3 \log \mathrm{CFU} / \mathrm{g}$. Eleven days later, on day 19, only 1 sample exceeded $2 \log \mathrm{CFU} / \mathrm{g}$. At the time of harvest, day 33, the number of E. coli in 5 of 15 soil samples was reduced below the detection limit (1 log $\mathrm{CFU} / \mathrm{g}$ ), and no samples contained more than $2 \log \mathrm{CFU} / \mathrm{g}$. Thus, the number of $E$. coli in soil from field 3 was found to decline to low levels within the 33-day growth period of lettuce.

Several studies indicate that $E$. coli can persist in manure-fertilized soil for several months after manure application $(29,30)$, implying a potential risk for vegetable crops to be exposed to pathogens. According to Ingham et al. (28), increasing the fertilization-to-harvest time intervals from 90 to 120 days decreased the prevalence of E. coli on lettuce grown in silty clay loam soils, whereas a similar decrease was not seen on lettuce cultured in loamy sand. Consequently, Ingham et al. (28) found few arguments for reducing the minimum fertilization-to-harvest time interval of 120 days for not-composted animal manure stated by the National Organic Program in the United States (1). In the current study, the highest percentage of E. coli-contaminated lettuce $(54 \%$ at field 3 ) coincided with the shortest growth period (33 days as opposed to 50 and 57 days) as well as the shortest time between application of slurry and harvest of lettuce compared with the other two fields (33 days as opposed to 57 and 129 days). Mootian et al. (37) also reported that in the period from 20 to 30 days after planting lettuce in manure-amended soil inoculated with $E$. coli $\mathrm{O} 157: \mathrm{H} 7$ (1 to $4 \log \mathrm{CFU} / \mathrm{g}$ ), the number of plants testing positive for E. coli O157:H7 decreased from 6 of 24 lettuce plants to 0 . According to the European Commission (18), it is only recommended to compost manure that is used to fertilize organic vegetables, which implies that the use of not-composted manure is not prohibited, and currently, there is no established minimum fertilization-to-harvest time interval for not-composted manure in Europe equivalent to the National Organic Program regulation (1). According to the National Organic Program regulations, "proper" composting implies that the stored manure reach a temperature above $55^{\circ} \mathrm{C}$ for several continuous days, depending on the level of aeration (stacked manure must be turned). The length of time needed to reach a satisfactory reduction of pathogens after fertilization depends also on the initial concentration in the manure (12), which again partly depends on the source, age, and storage conditions of the manure $(19,26,39)$. Storage of manure with no continuous input will decrease pathogen numbers, but the rate of decline varies due to the composition of the manure, temperature, and other physicochemical factors (5). Practices of manure application have been shown to vary considerably among organic vegetable producers (33). This was also the case for the three fields in our study, where the used livestock manure, e.g., had been stored for $<1$ month, 3 to 6 months, and $>6$ months before application. Despite the different storage time, the concentration of E. coli in the slurry at the time of application varied only $1.5 \log \mathrm{CFU} / \mathrm{g}$, and together with findings of $E$. coli-contaminated lettuce in all three fields, this could indicate that storage for less than 6 months is inadequate to prevent transfer of E. coli and thus potential pathogens to lettuce. Unfortunately, the varying manure practices between the three fields involved in the current study impair the conclusions on the relative importance of the timing of slurry application, type, and age of the slurry as well as the interval between application and planting, as more con- 
trolled experimental conditions would be necessary to address this.

Streptomycin-resistant E. coli was found in 9 of 15 soil samples 8 days after fertilization of field 3 , and ampicillinresistant $E$. coli was found in 1 soil sample (Table 1). The spread of antimicrobial-resistant genes into the environment, e.g., via slurry amendment of soil, is undesirable due to possible horizontal gene transfer between bacteria $(11,25)$. In this way, antimicrobial resistance encoding genes in plasmids, integrons, and other transposable elements can be transferred to the normal soil flora and potentially also to pathogenic bacteria (36).

Source of lettuce contamination. At harvest, on day $33,20 \%$ of the 50 lettuce pools from field 3 contained more than $2 \log$ E. coli per g, while E. coli in all soil samples had an $E$. coli concentration below $2 \log \mathrm{CFU} / \mathrm{g}$. This could indicate that the slurry used on field 3 might not have been the sole source of the E. coli contamination, and that was supported by the PFGE typing of 83 selected E. coli isolates from slurry, soil, and lettuce, which represented 21 different PFGE profiles (Table 2). Five of the 13 PFGE profiles found in the slurry were also found in soil samples, and 2 of these profiles were furthermore found in lettuce. Still, several different PFGE profiles were found on single occasions in either soil or lettuce, which indicates that the $E$. coli could originate from nonslurry sources, such as the surrounding environment or wildlife $(13,47)$. The finding of $E$. coli-negative soil samples prior to slurry application could in part be explained by sampling done immediately after plowing, reducing the chance of detecting any fecal pollution from wildlife. Similarly, Ingham et al. (29) found that low-level contamination with indigenous E. coli occurred sporadically for washed carrots, lettuce, and radishes, regardless of whether animal manure had been applied. Even insects were identified as a possible vehicle for transmission of E. coli O157:H7 (48). For further studies, it would be relevant also to sample lettuce from fields without prior slurry amendment to assess the "background" level of $E$. coli on lettuce.

The current study of $E$. coli (fecal indicator) levels in lettuce grown under natural conditions in slurry-amended soils revealed a frequent contamination $(44.9 \%)$ and levels above $2 \log \mathrm{CFU} / \mathrm{g}$ in $42.4 \%$ of the contaminated samples. This fecal contamination indicates a potential presence of pathogens such as Salmonella and Campylobacter, which could represent a real hazard to human health, as lettuce is typically eaten raw. Moreover, streptomycin- and ampicillin-resistant E. coli was found in 15.0 and $1.4 \%$ of the lettuce pools, respectively, which indicates a risk of transferring antimicrobial-resistant genes. The field with the highest percentage of lettuce contaminated with both susceptible and resistant E. coli (54.0 and 18.0\%) coincided with the shortest interval between application of animal slurry and harvest. This stresses the importance of the length of the time gap between slurry fertilization and harvest when reducing the risk of fecal contamination of lettuce. However, there was relatively high number of $E$. coli in lettuce at harvest as compared with the numbers found in the soil, and the majority of the PFGE profiles differed between $E$. coli isolates from slurry, soils and lettuce. This suggests that the animal slurry fertilization was not the sole source of fecal contamination, but that the surrounding environment and wildlife played a role in the contamination with E. coli.

\section{ACKNOWLEDGMENTS}

We gratefully acknowledge the financial support for this study provided by the members of the [Coordination of European Transnational Research in Organic Food and Farming] (CORE) Organic Funding Body Network, being former partners of the Sixth Framework Project (FP6) European Research Area Network project, CORE Organic (E.U. FP6 project no. 011716), which was finalized in September 2007. We also thank all persons involved in crop production and laboratory analysis for their skillful technical assistance.

\section{REFERENCES}

1. Anonymous. 2000. 7 CFR 205.203: Soil fertility and crop nutrient management practice standard. National Organic Program, United States Department of Agriculture, Washington, DC.

2. Anonymous. 2011. Annual report on zoonoses in Denmark 2010. National Food Institute, Technical University of Denmark, Søborg.

3. Arthur, L., S. Jones, M. Fabri, and J. Odumeru. 2007. Microbial survey of selected Ontario-grown fresh fruits and vegetables. J. Food Prot. 70:2864-2867.

4. Berger, C. N., S. V. Sodha, R. K. Shaw, P. M. Griffin, D. Pink, P. Hand, and G. Frankel. 2010. Fresh fruit and vegetables as vehicles for the transmission of human pathogens. Environ. Microbiol. 12:23852397.

5. Bicudo, J. R., and S. M. Goyal. 2003. Pathogens and manure management systems: a review. Environ. Technol. 24:115-130.

6. Brandl, M. T. 2006. Fitness of human enteric pathogens on plants and implications for food safety. Ann. Rev. Phytopathol. 44:367-392.

7. Buchholz, U., H. Bernard, D. Werber, M. M. Böhmer, C. Remschmidt, H. Wilking, Y. Deleré, M. an der Heiden, C. Adlhoch, J. Dreesman, J. Ehlers, S. M. Faber, C. Frank, G. Fricke, M. Greiner, M. Höhle, S. Ivarsson, U. Jark, M. Kirchner, J. Koch, G. Krause, P. Luber, B. Rosner, K. Stark, and M. Kühne. 2011. German outbreak of Escherichia coli O104:H4 associated with sprouts. N. Engl. J. Med. 365:1763-1770.

8. Buck, J. W., R. R. Walcott, and L. R. Beuchat. 2003. Recent trends in microbiological safety of fruits and vegetables. Online Plant Health Prog. doi:10.1094/PHP-2003-0121-01-RV.

9. Centers for Disease Control and Prevention. 2012. Multistate outbreak of E. coli O157:H7 infections linked to romaine lettuce. Available at: http://www.cdc.gov/ecoli/2011/ecoliO157/romainelettuce/032312/. Accessed 8 January 2013.

10. Cevallos-Cevallos, J. M., M. D. Danyluk, G. Gu, G. E. Vallad, and A. H. van Bruggen. 2012. Dispersal of Salmonella Typhimurium by rain splash onto tomato plants. J. Food Prot. 75:472-479.

11. Chee-Sanford, J. C., R. I. Mackie, S. Koike, I. G. Krapac, Y. F. Lin, A. C. Yannarell, S. Maxwell, and R. I. Aminov. 2009. Fate and transport of antibiotic residues and antibiotic-resistance genes following land application of manure waste. J. Environ. Qual. 38: 1086-1108.

12. Choi, S., J. Bang, H. Kim, L. R. Beuchat, and J. H. Ryu. 2001. Survival and colonization of Escherichia coli O157:H7 on spinach leaves as affected by inoculum level and carrier, temperature and relative humidity. J. Appl. Microbiol. 111:1465-1472.

13. Cooley, M., D. Carychao, L. Crawford-Miksza, M. T. Jay, C. Myers, C. Rose, C. Keys, J. Farrar, and R. E. Mandrell. 2007. Incidence and tracking of Escherichia coli $\mathrm{O} 157: \mathrm{H} 7$ in a major produce production region in California. Online PloS One 2:e1159. doi:10.1371/journal. pone.0001159.

14. Danish Integrated Antimicrobial Resistance Monitoring and Research Programme. 2010. Use of antimicrobial agents and occurrence of antimicrobial resistance in bacteria from food animals, food and 
humans in Denmark. ISSN 1600-2032. Available at: http://www. danmap.org/Downloads/Reports.aspx. Accessed 8 January 2013.

15. Doyle, M. P., and M. C. Erickson. 2008. Summer meeting 2007-the problems with fresh produce: an overview. J. Appl. Microbiol. 105: 317-330.

16. Erickson, M. C., C. C. Webb, J. C. Diaz-Perez, S. C. Phatak, J. J. Silvoy, L. Davey, A. S Payton, J. Liao, L. Ma, and M. P. Doyle. 2010. Infrequent internalization of Escherichia coli $\mathrm{O} 157: \mathrm{H} 7$ into field-grown leafy greens. J. Food Prot. 73:500-506.

17. European Commission. 2005. Commission Regulation (EC) No 2073/ 2005 on microbiological criteria for foodstuffs, amended by EC No 1441/2007/EC of 5/12/2007. Off. J. Eur. Union. Available at: http://eur-lex.europa.eu/literexUriServ/literexUriServ.do?uri=OJ:L:2005: 338:0001:0026:EN:PDF and http://eur-lex.europa.eu/literexUriServ/ literexUriServ.do?uri=OJ:L:2007:322:0012:0029:EN:PDF. Accessed 8 January 2013.

18. European Commission. 2007. Council Regulation (EC) No 834/2007 of 28 June 2007 on organic production and labelling of organic products and repealing Regulation (EEC) No 2092/91. Off. J. Eur. Union. Available at: http://eur-lex.europa.eu/literexUriServ/literex UriServ.do?uri =OJ:L:2007:189:0001:0023:EN:PDF. Accessed 8 January 2013.

19. Franz, E., M. M. Klerks, O. J. de Vos, A. J. Termorshuizen, and A. H. van Bruggen. 2007. Prevalence of Shiga toxin-producing Escherichia coli $s t x_{1}, s t x_{2}$, eaeA, and $r f b \mathrm{E}$ genes and survival of $E$. coli O157:H7 in manure from organic and low-input conventional dairy farms. Appl. Environ. Microbiol. 73:2180-2190.

20. Franz, E., A. D. van Diepeningen, O. J. de Vos, and A. H. van Bruggen. 2005. Effects of cattle feeding regimen and soil management type on the fate of Escherichia coli O157:H7 and Salmonella enterica serovar Typhimurium in manure, manureamended soil, and lettuce. Appl. Environ. Microbiol. 71:61656174.

21. Gravani, R. B. 2009. The role of good agricultural practices in produce safety, p. 101-117. In X. Fan, B. A. Niemira, C. J. Doona, F. E. Feeherry, and R. B. Gravani (ed.), Microbial safety of fresh produce. Wiley-Blackwell and IFT Press, London.

22. Guan, T. Y., and R. A. Holley. 2003. Pathogen survival in swine manure environments and transmission of human enteric illness-a review. J. Environ. Qual. 32:383-392.

23. Hassan, S. A., A. D. Altalhi, Y. A. Gherbawy, and B. A. El-Deeb. 2011. Bacterial load of fresh vegetables and their resistance to the currently used antibiotics in Saudi Arabia. Foodborne Pathog. Dis. 8: 1011-1018.

24. Heaton, J. C., and K. Jones. 2008. Microbial contamination of fruit and vegetables and the behaviour of enteropathogens in the phyllosphere: a review. J. Appl. Microbiol. 104:613-626.

25. Heuer, H., H. Schmitt, and K. Smalla. 2011. Antibiotic-resistance gene spread due to manure application on agricultural fields. Curr. Opin. Microbiol. 14:236-243.

26. Hutchison, M. L., L. D. Walters, S. M. Avery, and A. Moore. 2005. Decline of zoonotic agents in livestock waste and bedding heaps. $J$. Appl. Microbiol. 99:354-362.

27. Hutchison, M. L., L. D. Walters, S. M. Avery, F. Munro, and A. Moore. 2005. Analyses of livestock production, waste storage, and pathogen levels and prevalences in farm manures. Appl. Environ. Microbiol. 71:1231-1236.

28. Ingham, S. C., M. A. Fanslau, R. A. Engel, J. R. Breuer, J. E. Breuer, T. H. Wright, J. K. Reith-Rozelle, and J. Zhu. 2005. Evaluation of fertilization-to-planting and fertilization-to-harvest intervals for safe use of noncomposted bovine manure in Wisconsin vegetable production. J. Food Prot. 68:1134-1142.

29. Ingham, S. C., J. A. Losinski, M. P. Andrews, J. E. Breuer, J. R. Breuer, T. M. Wood, and T. H. Wright. 2004. Escherichia coli contamination of vegetables grown in soils fertilized with noncomposted bovine manure: garden-scale studies. Appl. Environ. Microbiol. 70:6420-6427.

30. Islam, M., M. P. Doyle, S. C. Phatak, P. Millner, and X. Jiang. 2004. Persistence of enterohemorrhagic Escherichia coli $0157: \mathrm{H} 7$ in soil and on leaf lettuce and parsley grown in fields treated with contaminated manure composts or irrigation water. J. Food Prot. 67:1365-1370.

31. Johannessen, G. S., G. B. Bengtsson, B. T. Heier, S. Bredholt, Y. Wasteson, and L. M. Rorvik. 2005. Potential uptake of Escherichia coli O157:H7 from organic manure into crisphead lettuce. Appl. Environ. Microbiol. 71:2221-2225.

32. Johnston, L. M., L. A. Jaykus, D. Moll, J. Anciso, B. Mora, and C. L. Moe. 2006. A field study of the microbiological quality of fresh produce of domestic and Mexican origin. Int. J. Food Microbiol. 112: 83-95.

33. Landau, B., M. Koller, and P. Mäder. 2011. PathOrganicidentification of critical control points for organic vegetable crops. Report, p. 1-36. Online Organic eprint. Available at: http://orgprints. org/20389/. Accessed 8 January 2013.

34. Lewis, H. C., S. Ethelberg, K. E. P. Olsen, E. M. Nielsen, M. Lisby, S. B. Madsen, J. Boel, R. Stafford, M. Kirk, H. V. Smith, S. Tikumrum, A. Wisetrojana, A. Bangtrakulnonth, J. Vithayarungruangsri, P. Siriarayaporn, K. Ungchusak, J. Bishop, and K. Mølbak. 2009. Outbreaks of Shigella sonnei in Denmark and Australia linked to consumption of imported raw baby corn. Epidemiol. Infect. 137: 326-334.

35. Lynch, M. F., R. V. Tauxe, and C. W. Hedberg. 2009. The growing burden of foodborne outbreaks due to contaminated fresh produce: risks and opportunities. Epidemiol. Infect. 137:307-315.

36. McDermott, P. F., S. Zhao, D. D. Wagner, S. Simjee, R. D. Walker, and D. G. White. 2002. The food safety perspective of antibiotic resistance. Anim. Biotechnol. 13:71-84.

37. Mootian, G., W. H. Wu, and K. R. Matthews. 2009. Transfer of Escherichia coli $\mathrm{O} 157: \mathrm{H} 7$ from soil, water, and manure contaminated with low numbers of the pathogen to lettuce plants. J. Food Prot. 72: 2308-2312.

38. Moyne, A. L., M. R. Sudarshana, T. Blessington, S. T. Koike, M. D. Cahn, and L. J. Harris. 2011. Fate of Escherichia coli O157:H7 in field-inoculated lettuce. Food Microbiol. 28:1417-1425.

39. Nicholson, F. A., S. J. Groves, and B. J. Chambers. 2005. Pathogen survival during livestock manure storage and following land application. Bioresour. Technol. 96:135-143.

40. Osterblad, M., O. Pensala, M. Peterzens, H. Heleniusc, and P. Huovinen. 1999. Antimicrobial susceptibility of Enterobacteriaceae isolated from vegetables. J. Antimicrob. Chemother. 43:503509.

41. Quiroz-Santiago, C., O. R. Rodas-Suárez, C. R. Vazquez Q., F. J. Fernández, E. I. Quiñones-Ramírez, and C. Vázquez-Salinas. 2009. Prevalence of Salmonella in vegetables from Mexico. J. Food Prot. 72:1279-1282.

42. Raphael, E., L. K. Wong, and L. W. Riley. 2011. Extended-spectrum beta-lactamase gene sequences in gram-negative saprophytes on retail organic and nonorganic spinach. Appl. Environ. Microbiol. 77:16011607.

43. Ribot, E. M., M. A. Fair, R. Gautom, D. N. Cameron, S. B. Hunter, B. Swaminathan, and T. J. Barrett. 2006. Standardization of pulsedfield gel electrophoresis protocols for the subtyping of Escherichia coli O157:H7, Salmonella, and Shigella for PulseNet. Foodborne Pathog. Dis. 3:59-67.

44. Sagoo, S. K., C. L. Little, and R. T. Mitchell. 2001. The microbiological examination of ready-to-eat organic vegetables from retail establishments in the United Kingdom. Lett. Appl. Microbiol. 33:434-439.

45. Scott, T. M., J. B. Rose, T. M. Jenkins, S. R. Farrah, and J. Lukasik. 2002. Microbial source tracking: current methodology and future directions. Appl. Environ. Microbiol. 68:5796-5803.

46. Solomon, E. B., S. Yaron, and K. R. Matthews. 2002. Transmission of Escherichia coli O157:H7 from contaminated manure and irrigation water to lettuce plant tissue and its subsequent internalization. Appl. Environ. Microbiol. 68:397-400.

47. Somarelli, J. A., J. C. Makarewicz, R. Sia, and R. Simon. 2007. Wildlife identified as major source of Escherichia coli in agriculturally dominated watersheds by BOX A1R-derived genetic fingerprints. J. Environ. Manag. 82:60-65. 
48. Talley, J. L., A. C. Wayadande, L. P. Wasala, A. C. Gerry, J. Fletcher, U. DeSilva, and S. E. Gilliland. 2009. Association of Escherichia coli $\mathrm{O} 157: \mathrm{H} 7$ with filth flies (Muscidae and Calliphoridae) captured in leafy greens fields and experimental transmission of E. coli O157:H7 to spinach leaves by house flies (Diptera: Muscidae). J. Food Prot. 72:1547-1552.

49. Tallon, P., B. Magajna, C. Lofranco, and K. T. Leung. 2005. Microbial indicators of fecal contamination in water: a current perspective. Water Air Soil Pollut. 166:139-166.

50. Viswanathan, P., and R. Kaur. 2001. Prevalence and growth of pathogens on salad vegetables, fruits, and sprouts. Int. J. Hyg. Environ. Health 203:205-213.
51. Walsh, C., and S. Fanning. 2008. Antimicrobial resistance in foodborne pathogens-a cause for concern? Curr. Drug Targets 9:808-815.

52. Wingstrand, A., T. Struve, A. I. V. Sørensen V. F. Jensen, and H.-D. Emborg. 2009. Antibiotikaresistens og -forbrug i slagtesvineproduktionen, p. 41-59. In H. Rosenquist, P. Sandøe, G. Tveit, A. Wingstrand, and S. Aabo (ed.), [Future food safetynew ways toward safer meat in Denmark]. Schultz Grafisk, Copenhagen.

53. Wu, S., E. Chouliara, L. B. Jensen, and A. Dalsgaard. 2008. Evaluation of Petrifilm Select E. coli Count Plate medium to discriminate antimicrobial resistant Escherichia coli. Online Acta Vet. Scand. 50:38 doi:10.1186/1751-0147-50-38. 